\title{
Employee Needs Analysis : Lancang Kuning University Case
}

\author{
Hasnati ${ }^{1}$ Bunga Chintia Utami and Trio Saputra \\ ${ }^{1}$ Universitas Lancang Kuning, Pekanbaru, Indonesia, 28265 \\ Tel: (0761) 53108-53236; Fax (0761) 52248 \\ E-mail : hasnati_tati@yahoo.co.id
}

\begin{abstract}
Performance of employees is a major concern for all organization. It's depend on workload. The availability of staff in Lancang Kuning University is not adjusted to the changing needs of the Organizational Structure and the workload of the employees. One preparation to Achieve the Strategic HR Planning Is that ripe with a set amount of human resources that is ideal to get UNILAK UNGGUL 2030. But, it will not happen if the distribution of employees have not Referred to the real needs of the organization. The distribution has not been based on the workload of the organization. Stacking employees in one unit without clear work and lack of staff in other units is a fact of the underlying problem at Lancang Kuning University. So in order to Achieve the performance of employees, we must to to be done structuring. In the implementation, Lancang Kuning University conducted an analysis of positions that include positions produce information Position Information Analysis. The purpose of this study is to projection of the Needed Employees with qualitative method. The research informants were selected from three institutions / units in the University of Lancang Kuning. The results of the workload analysis of staff at the University of Lancang Kuning can be done if there is clarity of guidelines or work instructions, a good understanding of the work guidelines to everyone, the suitability between work guidelines and knowledge of educational personnel. Based on job information and workloads, it is found that only two institutions are LPPM and BPM roomates is suitable of needs but in other side there are excess and lack, library excess 1 employee.
\end{abstract}

Keywords: Need Analysis, Employee, workload

\section{Introduction}

Availability Lancang Kuning University officials today considered not adapted to the changing needs of organizational structure and workload of employees. Inventories of employees is the number of employees who belong to a work unit at this time. In order to support the smooth implementation of the tasks of educators and educators in a faculty, the necessary number and quality of human resources is appropriate to be able to provide services for all stakeholders in an optimal (Nindi Aristi, 2014). knowing the employee supplies this year will make it easy forclickinghcounted inventory forecasts an employee at a period of years to come. Estimates on the number of employees consist of existing employees, reduced by the amount of the pension during the year. Reduction of employees outside of retirement such as transfer, promotion, stop, and dies hard to predict, so that these reductions are not included in the estimates.

In addition, the problem of availability in terms of quantity, it is necessary to note also the quality of employees (performance). Employee performance under the spotlight of various groups and institutions. The problems of employee performance is an important issue because the employee is considered less productive and low work ethic will be a source of waste and be a bad influence on other employees who have a good performance. Stigma was generally addressed to all employees, including the University of Lancang kuning.

Employee culture at the University of Lancang kuning similar to the work culture in other government agencies. It is shown from the cultural and environmental systems in government offices are generally more oriented toward public service and not to the product. As a result, the performance and discipline will always relate to the duties (roles, responsibilities, and functions) as well as the rules governing bureaucracy that is standard. To be able to carry out the work, the employee is always based on the technical and operational guidelines, SK, the work order, and the like. Therefore natural that in each unit and the work environment of government and universities many employees seem less productive.

However, it does not mean there are no employees who have potential. Currently just a lot of potential employees, but less chance to be empowered. The ability or the potential of the employees is dependent upon the respective superiors -masing in each work unit. If the boss in each unit to intelligently take policy in empowering subordinates, then there is a chance that employees will work according to their potential. So, the bad stigma on employee performance among employees will be lost if the potential employee was empowered suit its domain expertise and has managed by the leadership of the right. 
One of the main causes of low performance of employees is the occurrence of a mismatch between the competence of the employees to the position it occupies. Mismatches caused by the composition of the membership or employee skills are not proportional. Similarly, the distribution of employees still refer to the real needs of the organization, which means that the distribution is not based on the workload of the organization. The backlog of employees in one unit without any specific job and the lack of employees in other units is the reality of the problem. On the other hand the formation of the organization tend to be based on real needs, in terms of organization formed too large while the workload is small, so as not to organizational objectives efficiently and effectively. So in order to achieve the expected gains of employees who need to do the arrangement,

in the implementation of the arrangement, Lancang Kuning University conduct job analysis provides information covering positions Position Description, Terms Position, Map Position and Strength Employees. If the information office is available, the Lancang Kuning University undertake a reconsideration of the job information. To facilitate in preparing or reviewing information office, Lancang Kuning University uses the example of office information that has been compiled by BKD agencies that have adapted to the legislation and the need Lancang Kuning University.

Structuring employees include aspects of quantity, quality, composition, and distribution. The first phase is set arrangement Aspects existing quantity in order to obtain the number of employees in accordance with the needs of the organization, while the quality aspect, composition and distribution will be regulated in further Rector. Implementation of the Arrangement include the following steps:

1. Count the number of required staff conducted in accordance with the statutes and other laws

2. Elaborate structural and functional positions (job analysis)

3. Develop a map of positions by analyzing the gap between employee profiles with terms of office.

4. Analysis of the workload.

5. Determinutesing Category Number of Employees by comparing the calculation results with the employee needs any office of the existing number of employees, such as employee number Less categories (K), Match $(\mathrm{S})$, and More (L).

6. Projected needs of employees for 5 years

7. an employee redistribution plan report

8. Report on the evaluation and recommend follow-up measures

The research will focus on the calculation of the workload of employees based on their respective work units. Before calculating the work load, job analysis is done first. Job analysis aims to look at employee understanding of the job description, job specification and job conditions.

\section{Method}

The research method used Concurrent Mixed Method Triangulation, ie in-depth research by analyzing both quantitative and qualitative methods well then both in comparison (Creswell, 2009). Comparative analysis of positions is expected to be obvious, then the results of research carried out can be used to determinutese the predictive kuning sassy needs of university employees, the study's respondents kuning sassy university employees 60 people and ordinary 9, 1 key informants and informant. Data was collected by using a questionnaire for the quantitative method for qualitative methods while using interviews and comes with documentation.

\section{Job Analysis}

Job analysis is a process of collecting, research, the data decomposition stage position includes the step of preparation and planning, phase of data collection and data processing stage. The implementation stage is described as follows:

1. planning and preparation phase At this stage some of the activities carried out are:

a. Reaffirmation of the organizational structure that will be a guide for subsequent processes, including the names of title and place.

b. Inventory existing positions in each work units and collated based on hierarchy and given an identification code

c. Establish data collection methods to be used and set up tools and equally necessary (form etc.)

d. Forminutesg fielded the analysis and describes the methods to be used,

e. Communication / explanation by the leaders of work units and all employees of the intent and purpose of job analysis to be carried out.

In order to obtain qualified employees expected, the best way to be done by the leader of an organization is to conduct job analysis or job analysis so that it can see the type and competence of employees required for an organization (Muhammad rizky ramadhan, yoanita yunianti, 2014) government regulations on office management Hours of work Ideal employee that is 72,000 minutes / year (Kepala BKN, 2011) the effectiveness and efficiency of work is a comparison between the weight of work with the normal conditions of the stakeholders to complete the tasks and functions of the organization (Negeri, 2008)

\section{Data Collectionphase}

The data collectionpositions can be done in several ways:

a. Methods of Observation and Interview. An observation method means executing a job analysis to directly observe on the spot how job tasks performed and recorded to process into information. While the method of interviewing officers interviewed directly incumbent 
analysis by asking questions in the first set and record the answer to be processed into information necessary

b. questionnaire Methods (List of Questions). Data collected through the deployment of a questionnaire to all employees to fill them. The list of questions could be "open" (Open ended) means, answering should give an answer according to his own will in its own way, is not restricted.

3. Phase Data Processing. After the data collection process was completed, the data processing is:

a. Determinutesing factors of appraisal office

b. Determinutesing the weight value of each factor c. analysis of the interviews and questionnaires that have been in the content

d. analysis of job requirements

e. Develop job descriptions

f. Doing patterns ratings workload as the basis of the determinutesation of the system

\section{Results and Discussion}

Distribution of employees based on work unit can be seen in Table 1 below.

Table 1. Distribution of Employees Under the Work Unit

\begin{tabular}{cc}
\hline No & Unit \\
\cline { 2 - 2 } & \\
\hline 1 & LPPM (Lembaga Penelitian dan Pengabdian Masyarakat) \\
2 & BPM (Badan Penjaminan Mutu) \\
3 & BHE (Badan Hukum dan Etika) \\
4 & Perpustakaan \\
\hline
\end{tabular}

Based on table 1 above it can be seen that the educational staff with the status of education personnel in institutions / unit environment Lancang Kuning University. This study focuses on the permanent staff in 4 units / institutions.

\section{Library}

Optimization of work to do when the number of employees in accordance with the amount of workload. Based on the results of form filling information office, it is known that the workload associated with job descriptions include:

1. Providing service borrowing and returning books

2. Manage Feasibility computer device

3. Caters to college students looking for theses, books, journals and other

4. inventory of theses, books, journals and other

5. recapitulate and data input to the system of OPAC, such as data theses, books, journals and other incominutesg

6. doing checking and repairs to the thesis that damaged
Number of Employees

$\begin{array}{ccc}\text { Permanent } & \text { Contracts } & \text { Contract } \\ & \text { University } & \text { Institution }\end{array}$

3-1

1

1

7. Making newspaper clippings

8. Processing fines student who fails to return the book

9. doing routine tasks adminutesistrative offices such as sorting the incominutesg and outgoing mail, manage finances and making financial reports, monthly coordination meeting

10. of library materials procurement

11. Print and CopyService

Servicesborrowing and returning books given to both students and lecturers environment Lancang Kuning University and outside the University Lancang Kuning. Services are provided to the 50 to 100 people every day. Everyone is served about 5 minutesutes. Thus, in the first day of service spent about 500 minutesutes / day or 120,000 / year. Details of the workload based on the task can be seen in the table below.

Table 2 Details of Output and Turnaround Time Job

\begin{tabular}{|c|c|c|c|}
\hline No. & Job Description & Output & $\begin{array}{c}\text { Time } \\
\text { (1 Year) }\end{array}$ \\
\hline 1 & Providing service borrowing and returning books & 100 students / day & 120000 minutes \\
\hline 2 & Manage Feasibility computer device & 12 Activity /week & 1440 minutes \\
\hline 3 & $\begin{array}{l}\text { Caters to college students looking for theses, books, journals and } \\
\text { the other on the rack provided }\end{array}$ & 50 students / day & 60.000 minutes \\
\hline 4 & inventory of theses, books, journals and other & 4 activities / week & 2880 minutes \\
\hline 5 & $\begin{array}{l}\text { recapitulate and input data to the OPAC system, such as data } \\
\text { theses, books, journals and other entry }\end{array}$ & 8 activities / week & 5760 minutes \\
\hline 6 & perform checking and repairs to the thesis that damaged & four activities / week & 5760 minutes \\
\hline 7 & Creating a newspaper clipping & of 4 activities / week & 5760 minutes \\
\hline 8 & Processing fines student who fails to return the book & 10 students / day & 12,000 minutes \\
\hline 9 & $\begin{array}{l}\text { Doing routine tasks such as sorting incominutesg and outgoing } \\
\text { mail, managing finances and making financial reports, monthly } \\
\text { coordination meeting }\end{array}$ & 1 activity / day & 7,200 minutes \\
\hline 10 & Acquisition of library materials & 4 events /week & 480 minutes \\
\hline
\end{tabular}




\begin{tabular}{|c|c|}
\hline Print and Copy Service & 43,200 minutes \\
\hline Total Time & $\begin{array}{l}264480 \text { minutes } \\
\text { / year }\end{array}$ \\
\hline Workload & 3.67 \\
\hline Employee Needs & 4 \\
\hline $\begin{array}{l}\text { Timecompletion of the work in the first year in } \\
\text { which the Library } 264480 \text { minutes / year divided by the } \\
\text { effective working time } 72.000 \text { minutes / year so, the } \\
\text { number of employees to efficiently this section is four ( } 4 \text { ) } \\
\text { out of the five (5) existing employees. This means that this } \\
\text { unit has an excess number of employees as much as } 1 \\
\text { (one). }\end{array}$ & $\begin{array}{l}\text { 6. doing checking and repairs to the thesis that } \\
\text { damaged } \\
\text { 7. Making newspaper clippings } \\
\text { 8. Processing fines student who fails to return the book } \\
\text { 9. doing routine tasks adminutesistrative offices such } \\
\text { as sorting the incominutesg and outgoing mail, } \\
\text { managing finances and making financial reports, } \\
\text { monthly coordination meeting }\end{array}$ \\
\hline Based on the results of form filling information & 10. of library materials procurement \\
\hline office, it is known that the workload associated with job & 11. Print and CopyService \\
\hline descriptions include: & Services borrowing and returning books given to \\
\hline 1. Providing service borrowing and returning books & both students and lecturers environment Lancang Kuning \\
\hline 2. Manage Feasibility computing devices & University or from outside environment Universit as \\
\hline $\begin{array}{l}\text { 3. Serving students seeking theses, books, journals and } \\
\text { other racks available }\end{array}$ & $\begin{array}{l}\text { Lancang Kuning. Services are provided to the } 50 \text { to } 100 \\
\text { people every day. Everyone is served about } 5 \text { minutesutes. }\end{array}$ \\
\hline 4. inventory of theses, books, journals, and more & Thus, in the first day of service spent about 500 minutesutes \\
\hline $\begin{array}{l}\text { 5. recapitulate and input the data into the system of } \\
\text { OPAC, such as data theses, books, journals and }\end{array}$ & $\begin{array}{l}\text { / day or } 120,000 \text { / year. Details of the workload based on } \\
\text { the task can be seen in the table below. }\end{array}$ \\
\hline
\end{tabular}

Table 3 Details of Output and Turnaround Time Job

\begin{tabular}{|c|c|c|c|}
\hline No & Job Description & Output & Time (1 Year) \\
\hline 1 & Providing service borrowing and returning books & 100 students / day & 120000 minutes / year \\
\hline 2 & Manage Feasibility computer device & 12 Activity /week & 1440minutes / year \\
\hline 3 & $\begin{array}{l}\text { Caters to college students looking for thesis, books, journals } \\
\text { and others on the shelf that provided }\end{array}$ & 50 students / day & 30,000 minutes / year \\
\hline 4 & inventory of theses, books, journals and other & 4 activities / week & 2880 minutes / year \\
\hline 5 & $\begin{array}{l}\text { recapitulate and input the data into the system of OPAC, such } \\
\text { as data thesis, books, journals and other incominutesg }\end{array}$ & 8 activity / week & 5760 minutes / year \\
\hline 6 & Perform checking and repairs to the thesis that damaged & four activities / week & 5.760 minutes / year \\
\hline 7 & Creating a newspaper clipping & four activities / week & 5760 minutes / year \\
\hline 8 & processing fines student who fails to return the book & 10 students / day & 12,000 minutes / year \\
\hline 9 & $\begin{array}{l}\text { doing routine tasks such as sorting incominutesg and } \\
\text { outgoing mail, managing finances and making lapo financial } \\
\text { ran, the monthly coordination meeting }\end{array}$ & 1 activity / day & 7,200 minutes / year \\
\hline 10 & Acquisition of library materials & 4 events / & 480minutes / year \\
\hline \multirow[t]{4}{*}{11} & Print and Copy Service & 1 activity / day & 43,200 minutes / year \\
\hline & Total Time & & 234480 minutes/ year \\
\hline & Workload & & 3.25 \\
\hline & needs employees & & 4 \\
\hline
\end{tabular}

time of completion of work in one year in the Library ie 264480 minutes / year divided by the effective working time 72.000 minutes / year so, the number of employees who are efficient for this section is four (4) out of the five (5) employees who already available. This means that this unit has an excess number of employees as much as 1 (one)

\section{Institute for Research and Community Service (LPPM)}

Based on information form filling positions, it is known that the workload associated with LPPM job descriptions include:

1. Doing Assistance improvement proposals APBF, APBU and Higher Education

2. Conducting Research and Services APBF

3. Conducting Research and Services APBU

4. Conducting Research and Service of Higher Education

5. trainings to

6. enter the performance 
7. inventory of incominutesg and outgoing mail

8. Making financial reports, meeting monthly coordination

Service Assistance improvement proposals APBF, APBU and Higher Education awarded to lecturers environment of the University of Lancang Kuning. Funded research and service with as many as 70 proposals APBU scheme, APBf as many as 100 proposals and 40 proposals of Higher Education scheme. Each mentoring, LPPM do the checking against the proposal format. Usually one proposal could be improved as much as 2-3 times. Each correction process takes about 15 minutesutes. So that 218 proposals with a repair requires 6540 minutesutes / year. Details of the workload based on the task can be seen in the table below.

Table 4 Details of Output and Turnaround Time Job

\begin{tabular}{|c|c|c|c|}
\hline No. & Job Description & Output & $\begin{array}{c}\text { Time } \\
\text { (1 Year) }\end{array}$ \\
\hline 1 & $\begin{array}{l}\text { Perform Assistance improvement proposals APBF, } \\
\text { APBU And DIKTI }\end{array}$ & 218 documents / year & 6540 minutes / year \\
\hline 2 & merekap data and examinutese proposals APBF & 1 events / year & 48,000 minutes / year \\
\hline 3 & recap data and examinutese proposals APBU and DIKTI & 1 events / year & 48,000 minutes / year \\
\hline 4 & $\begin{array}{l}\text { Melakaksanakan Preparation Research and Services } \\
\text { APBF, APBU and DIKTI like to contact the reviewer } \\
\text { and prepare for the adminutesistration of }\end{array}$ & 3 events / year & 24000 minutes / year \\
\hline 5 & training in & 5 events / year & 3000 minutes / year \\
\hline 6 & input performance & 2 events / & 1200 minutes / year \\
\hline 7 & Make activity Report & 5 events / year & 3000 minutes / year \\
\hline 8 & Make Financial Statements & 12 events / year & 7200 minutes / year \\
\hline 9 & inventory of incominutesg and outgoing mail & 1 events / year & 2400 minutes / year \\
\hline 10 & Meeting monthly coordination & 12 activities / year & 2160 minutes / year \\
\hline 11 & Dropping Letter & 1 Activity / year & 7200 minutes / year \\
\hline 12 & Make SOP & 1 Activity / year & 6000 minutes / year \\
\hline \multirow[t]{4}{*}{13} & $\begin{array}{l}\text { Assisting and } m \text { engontrol information on information } \\
\text { systems RISTEK DIKTI }\end{array}$ & $\begin{array}{l}1 \text { Activity / Year } \\
\text { 30x20x } 12\end{array}$ & 7200 minutes / year \\
\hline & Total Time & & 165900 minutes / year \\
\hline & Workload & & 2.3 \\
\hline & Needs Employees & & 3 \\
\hline
\end{tabular}

Time of completion of work in one year in LPPM ie 165900 minutes / year divided by the effective working time of 72,000 minutesutes / years so, the number of employees to efficiently this section is three (3) persons. It shows that in this unit already has a number of employees in accordance with the workload.

\section{References}

[1]Creswell, J. W. (2009). Research Design Pendekatan Penelitian Kualitatif, Kuantitatif, Dan Mixed. Yogyakarta: Pustaka Pelajar.

[2] Kepala BKN. (2011). Pedoman Pelaksanaan. Analisis Jabatan. Jakarta.

[3] Muhammad Rizky Ramadhan, Yoanita Yunianti, Sugih Arijanto. (2014). Analisis Beban Kerja Dan Pengukuran Gap Kompetensi Teknisi Laboratorium Umum Dan Fakultas Z PTS XYZ. Jurnal Insitutr Teknologi Nasional, 2(3), 384-394.

[4] Negeri, M. D. (2008). Perhitungan Beban Kerja Dalam Rangka Menyususn Formasi Pegawai. Jakarta.

[5] Nindi Aristi, Hanny Hafiar. (2014). Analisis Beban Kerjatenaga Pendidik Dan Kependidikan Di Fakultas
Y Universitas X. Jurnal Kajian Komunikasi, 2(1), 53-60. 